\title{
THE POLITICS OF TRANSLATING ETHNOGRAPHIC IDEOSCAPES: THE DEATH AND LIFE OF AIDA HERNANDEZ: A BORDER STORY
}

\author{
Rachael Anneliese Radhay 1 \\ 1Universidade de Brasília, Brasília, Distrito Federal, Brasil
}

\begin{abstract}
The ecology of immigration discourse is an ideoscape in flux. It is a landscape constructed along human mobility, lifeworlds, ontological state security as well as along emotional and institutional complexities. There has been significant recent proliferation of border literature and ethnographies that represent narratives of migrants on the U.S-Mexico border. Ethnography as non-fiction literature documents border trajectories. This paper seeks to address how these trajectories are represented and or translated through a case study of the non-fiction work, The death and life of Aida Hernandez: a border story by Aaron Bobrow-Strain (2019) in which there is a distinct ecology in the ethos of ethnography and immigrant criminalization. This case study assesses therefore the relation between the politics of ethnographic ideoscapes, translation and agency based upon Critical Discourse Analysis (Wodak \& Kollner, 2008; Wodak \& Meyer, 2016) as well as evaluation and decision-making (Munday, 2012) when translating ethnography as a genre of represented voices.
\end{abstract}

Keywords: Ethnography; Agency; Institutional Habitus; Lifeworlds; Translation

\section{A POLÍTICA NA TRADUÇÃO DE IDEOSCAPES ETNOGRÁFICOS: THE DEATH AND LIFE OF AIDA HERNANDEZ: A BORDER STORY}

Resumo: A ecologia do discurso imigratório é uma paisagem ideológica em fluxo (um ideoscape). É uma paisagem construída com base na mobilidade humana, nos mundos pessoais (lifeworlds), na segurança ontológica, 
e também, nas complexidades emocionais e institucionais. Nos últimos anos, há bastante produção de literatura e de etnografias de fronteira, que representam as narrativas de migrantes na fronteira E.U.A.-México. A etnografia como literatura não-ficção serve para documentar as trajetórias de fronteira. Neste trabalho, propõe-se examinar como essas trajetórias são representadas e ou traduzidas em um estudo de caso da obra não-ficção, The death and life of Aida Hernandez: a border story escrita por Aaron Bobrow-Strain (2019) em que existe uma ecologia distinta no ethos da etnografia e na criminalização do imigrante. Neste estudo de caso, avalia-se a relação entre a política de paisagens etnográficas, a tradução e a agência com base na Análise Crítica de Discurso (Wodak \& Kollner, 2008; Wodak \& Meyer, 2016) e também em questões de avaliação e tomadas de decisão (Munday, 2012) na tradução de etnografia como um gênero de vozes representadas e representativas.

Palavras-chave: Etnografia; Agência; Habitus Institucional; Lifeworlds; Tradução

People close to Aida saw value in her life and dignity in her survival, but to outside observers the facts of her story wouldn't fit images of the model immigrant. Aida's teen pregnancy and struggles with poverty, her shoplifting offense, and her humanitarian visa overstay would burden the case. Her false citizenship claim at the border would probably sink it. Letters of support from community members in Douglas might help, but the ultimate outcome rested almost entirely on Aida's self-presentation. Aida and Jesse began to work together on her testimony (Bobrow-Strain, 280:2019).

Mobility and border spaces do not imply a simple dislocation from one point to another. Dislocation involves other issues: border institutionality (Balibar). This institutionality is constructed along knowledge regimes and evaluative procedures vis à vis humanitarian and criminalization issues (Blommaert; Walters, 158). The frontier is both an institutional narrative as well as individual lifestories - it is a transnational framework. Text genres are complex discursive spaces in which translation is linked to the ethics of recognition. Mobility and the dispute for legal recognition is a contradictory binary space 
in which the sociology of actors is constructed discursively between "us" and "them", that is, through the labelling of social actors, the generalization of negative attributes and the institutional argument to exclude or include specific groups. Given historical norms, discursive constructions may intensify or mitigate, make less or more implicit tolerance as well as norms to be politically correct in the public sphere (Wodak \& Koller). Immigration discourse fits into an institutional habitus as well as the immigrant's lifeworld. It presupposes power relations and networks, naturalized and constructed in immigration discourse. This discourse and power refer to hierarchies in contexts in which multiple truths are constructed vis à vis immigration. These truths are arguments that empower State hegemony in which the immigrant is constructed either as a menace to national security or as a threat to the labor market; or as highly skilled workers, inserted on the market or in other derogatory, metaphorical terms (Santa Ana). At the same time, revindications from human rights groups as well as legal norms on human rights generate other public discourses within institutional discourse. Thus, study focuses on the non-fiction work, The death and life of Aida Hernandez with a view to understanding the relation between control, discipline, agency and the immigrant's institutional trajectory given that mobility does not imply a mere dislocation from one place to another; human flows provoke the problematization of mobility due to securitization and criminalization. The policing of human flow is symbolic, in other words, security is public patrimony, a value or a right, a demand of citizens (Amicelle et al., 167; 169). Criminology in mobility cannot be ignored, borders are not always seen as humanitarian landscapes but as spaces of conflict.

They are spaces in which sovereignty apparently becomes fragmented in the shop window of social and humanitarian inclusion; protection of citizens; crime and the stigma of criminalization. Understanding the link between crimmigration and criminalization in migration contexts and the dispute for borders and citizenship in the determining of members reveals the conflict and empathy in public sphere discourses, the boundaries of policy and legislation and 
the counternarratives of documented and undocumented migrants (De Fina; Van Dijk). According to Stumpf, membership theory has to do with two strategies employed by the sovereign state: the power to punish and the power to express moral condemnation (15). Immigration is built along moral filters. Based upon a legitimising and argumentative framework (Van Leeuwen; Ellis), it is possible to recognise the foreigner in judicial and or social terms. Objectively, the "State" is defined legally, it is considered as a sovereign state power both internally as well as externally, as a space, it is a clearly demarcated area - State territory. In addition to this legal definition, the "nation" also means a politically demarcated community with a common ascendency, tied at least to a common language, culture and history... a national origin, attributed by others, associated from the beginning as a negative demarcation between what is native and foreign (Habermas, 129-130; 132).

In this sense, state immigration discourse is bureaucratic and at the same time strategic: the bureaucracy of laws and legal procedures together with State talk serve to construct a favourable image - a scenario of imagined stability, legitimised in legal-institutional language that cocoons against the disturbing scenarios of human dislocation - "ethnoscapes" in movement (Anderson; Appadurai).

The steoreotypes of State bureaucracy do not exist in a social vacuum (Herzfeld, 77); they emerge out of relations between social actors in contexts of power, relative to circumstances and situations, national and neoliberal ideologies, systems of classification or meaning and securitization (Arcarazo \& Freier; Barrero \& Van Dijk). The notion of "securitization" has to do not only with economic and territorial issues but refers to the nation-State's ontological security, the construction of immigrants in a negative and excluding manner cultivates the State's ontological security and its immutable sovereignty. In Germany, William (2014) discusses national narrative and citizenship. Among other studies, Santana's extensive work on metaphors used to describe latinos in U.S. public policy stands out $(1992 ; 2002)$. Another study on the use of metaphor in immigration is by Strauss (2013). Carminero-Santangelo (2016) 
provides an in-depth overview of border literature, a history of immigration policies in the United States and immigrants' stories in relation to trauma and genres used in documenting latino border lives. This work is quite significant when considering the emotional gap or hierarchy embedded in public stance and lifeworlds. In Ibrahim (2005), changes in Canadian immigration policy are mapped according to "securitization in migration", hinged along a new type of racist discourse. Ceyhan and Tsoukala (2002) look at discourses underlying securitzation of migration in western societies; they consider that these discourses are based on the myth: immigrants are always a threat to national security, thus the securitization argument justifies the latter's exclusion. Stumpf (2006) carries out a detailed ethnographic study on detention centers for foreigners in the United Kingdom as he explores the complexities of detention in immigrant lifeworlds. For Chilton (2004), securitization is a coercive, legitimising lexicalization in that it generates fear, stemming from the presupposition that immigrants are a physical or economic threat to the host nation. For example, detention centres in the United Kingdom are even more common and are ambivalent spaces of humanity, crimmigration and criminalization (Silverman; Bosworth)

The focus of this study is to look at border control interactions and lifeworlds in the US-Mexico border context through the ethnographic biographical work constructed in The life and death of Aida Hernandez. The expectation is to generate qualitative and quantitative data with respect to humanitarian rulings. It is essential to remember that the public-institutional sphere is based upon power and hierarchies that are expressed not only in grammatical forms but also have to do with control and dominance of the social occasion, the text genre, regulation of access and specific public spheres and the actors involved (Van Dijk, qtd. Gee \& Handford; Reisigl \& Wodak). The text genres and the social occasion are controlled and written by the institutional hegemony, that is by the state's persuasive institutional voice in which truths are determined. Truth is obviously linked to power, to the prestige of certain types of knowledge and texts and to specific social networks. It exists in ideological nodules or acts: 
what do they hide? What do they reveal? What do they legitimise? What do they value? There is an argumentative framework involved in which engagement in terms of crime, humanitarian ethics and legality is measured. The outline below is constructed according to modalities - humanitarian stance as well as border protection are weighed value decisions, there is always deliberation as to what should or should not be done in service to the state, national security but also in service to humanitarian issues without going beyond good sense: public sphere theory in action.

\section{Argumentative framework}

\begin{tabular}{|c|c|}
\hline Claim (solution) & 'we should do x' (should, must, ought to) \\
\hline Circumstantial premises & $\begin{array}{l}\text { Because we ought to be concerned about: } \\
\text { Context of action: natural, social, } \\
\text { institutional facts (e.g. promises, moral } \\
\text { values, duties, commitments) - 'world A' }\end{array}$ \\
\hline Goal premises (there can be more than one) & $\begin{array}{l}\text { And we ought to be concerned for reaching: } \\
\text { Future state of affairs, in which values, } \\
\text { commitments, or concerns are realised - } \\
\text { 'world B' }\end{array}$ \\
\hline Value premises - (values determine goals) & $\begin{array}{l}\text { Because it is in line with these values e.g. } \\
\text { 'fairness' or 'justice'; the right thing to do }\end{array}$ \\
\hline Means-goal premise & $\begin{array}{l}\text { We should do ' } x \text { ' because it will presumably } \\
\text { take us from 'world A' to 'world B' }\end{array}$ \\
\hline Alternative options (consequences) & $\begin{array}{l}\text { We shouldn't do ' } x \text { ' because ' } y \text { ' might } \\
\text { happen, but we could do ' } z \text { ' (or, several } \\
\text { other alternatives) }\end{array}$ \\
\hline $\begin{array}{l}\text { Addressing alternative options (counter- } \\
\text { argument) }\end{array}$ & $\begin{array}{l}\text { But, if we do ' } z \text { ' there will be some negative } \\
\text { consequence, or it will interfere with value } \\
\text { premises or goal premises }\end{array}$ \\
\hline
\end{tabular}

Source: (Ellis, 2017, adapted from Van Leeuven, 2007) 
Hence, the following questions must be taken into account in analysing border control or other text genres produced within the scope of immigration:

i. How is immigration constructed in the public sphere? (Koller \&Wodak).

ii. How can control be "argued" without discriminating and or excluding? (Argaman).

iii. How are text genres organized in regulating and evaluating interactions in institutional contexts? (Oberhuber; Munday).

iv. How is a specific discourse interpreted or transmitted in diverse social groups? (Oberhuber).

Ethnography reveals the evaluative, ontological ideoscapes involved in the aforementioned questions and in the argumentative framework presented previously. It unveils issues of power, mobility, access and control tied up in genre and language hierarchies as to what should or should not be done. According to Munday: "evaluative language is in many ways the bridge between the central concepts of ideology and axiology" (12). Ethnography, moreover constructs an empowering narrative on trauma, gender, family and criminalization (Bobrow-Strain, 232). Ethnography captures both the subject's public as well as personal trajectory: the narrative is both pubic as well as particular (Baker; CarmineroSantangelo; de Fina). Narratives engage institutional voices as well as immigrants' counter-narratives (Andrews).

The death and life of Aida Hernandez captures the trauma involved in Aida's lifeworld experiences and her anxiety in seeking to obtain US residence. As an ethnographic biography, the non-fiction work is a sensitive text. Indeed, ethnography is a "translation" not only of institutional voices but of undocumented voices. It moves along multiple spaces (Gustavson \& Cytrnbaum). According to Sturge (1), ethnographies are representative texts in which "translation is closely bound up with the power relations between the cultures involved". 
Further, it is a complex genre woven around interviews, diaries, testimonies and narratives. Nevertheless, it seeks to give voice to the undocumented (De Fina, 223; Inowlocki \& Lutz, 316). Ethnography implies a translation of complex realities in immigration: "but whereas ordinary translation takes as its object a piece of language already somewhat decontextualized and depersonalized, ethnographic translation is faced with 'raw' words hovering around the mouths and ears that produced them" (Sturge, 22). Bobrow-Strain, a political scientist explains his construction of the book as a project occupying

a space between journalism and ethnography, with a dash of oral history and biography. One thing it is not is firstperson testimony. Instead, the book emerged out of a long process of intensive collaboration...In the end, though, I was the author. This meant confronting the way my very different social position and personal experiences shaped the story and my relationship with Aida (169).

Ethnography problematizes translation and social interaction (Polezzi). It records the psychic (Christian \& Churchill, 5) as well as legal dilemmas of moral recognition as this is linked to who becomes visible or remains invisible in terms of legal residence, citizenship or deportation (Domenech; Marinucci). Within the legal immigration context, immigration is not only human diaspora. There is a sociology of actors involved in the legal ruling; circumstantial arguments must be organized and represented according to truth values in institutional knowledge vis à vis social imagery and social indifference (Angermuller; Bloor; Herzfeld; Van Dijk) as seen in the excerpt below:

If Jesse could prove to the court that David was a U.S. citizen, the case would hinge on Aida's ability to convince the judge and government attorneys of three things; that she 
was a person of good moral character, that she had suffered cruelty and abuse, and that deportation would create extreme hardship for her and her son. Because Aida never reported David to the police, all they had to offer were letters from family members and Aida's own voice. In cases like this, outcomes often came down to highly subjective judgments about whether a particular woman looked and sounded credible (Bobrow-Strain, 297).

Translation and interpreting may or may not play a role in the process of legal recognition (Gustavson et al; Munday). The main protagonist suffers the tension of narrating herself to U.S immigration authorities and at the same time she seeks to help her fellow inmates at the Eloy detention center as an informal translator:

INSIDE THE COURTROOM. Aida felt meek and intimidated. Over the course of seven preliminary hearings, she had not said much more than 'Yes, Your honor' and 'Thank you, Your honour," Outside, though, Anida had come into her own. She still helped her pod mates with translations for free, and a number of them had begun to trust her judgment (Bobrow-Strain, 297).

In fact, the issue of translation surfaces in the book in terms of access and do knowledge regimes. Undocumented workers fall into the trap of signing deportation agreements because they do not understand English. The book on the whole provides in a detailed manner the production of immigration knowledge and the difficult dialogue in the use of this knowledge given the barriers faced by undocumented immigrants in attempting to use this knowledge (Duchêne et al.,; Scholten, 288). 


\section{Figure 1.}

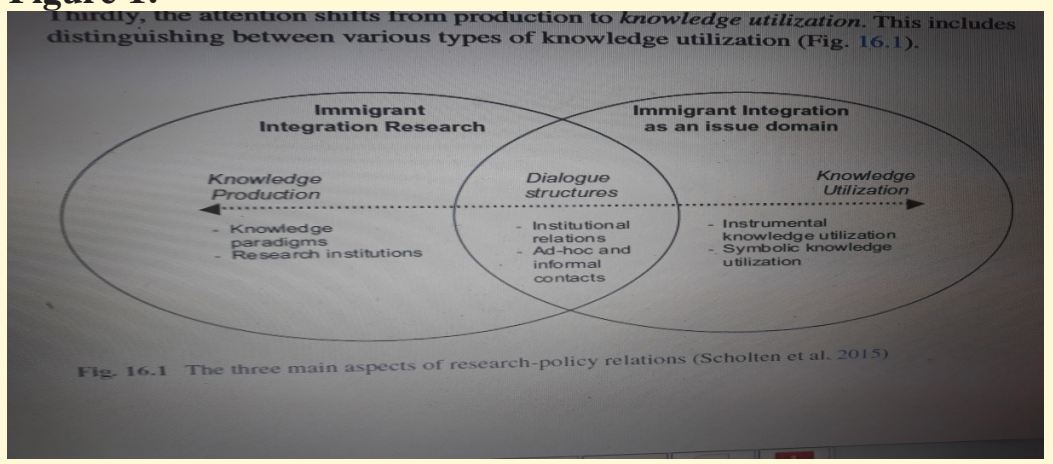

Source: (Scholten, 2018:288)

Mediation is not necessarily facilitated:

Aida nodded like a therapist. She had devised a strategy that worked for other women. 'Find a lawyer who offers free interviews,' she instructed Katy. 'Go to the consultation and learn everything you can. Ask a lot of questions. Then find another and another. Little by little you can figure out what you need to do for your case' (Bobrow-Strain, 282).

She becomes her own mediator and translator for her detention mates. She strives to work with linguistic and literacy barriers (Capstick). Indeed, the ethnography provides insight as to how text genres, language and immigration values are interlinked through its historical tracing of U.S. immigration laws regarding the U.S.Mexico border and the story of Aida's trajectory to the United States. Ideological positioning as well as the ethics of recognition are important issues to be considered when weighing genres and lexical choices in an analysis and translation of The death and life of Aida Hernandez. As an ethnography it is in itself a translation - it is value-laden. The writer himself provides a glossary in English of Spanish words and expressions as well as definitions 
of certain immigration terms. Nevertheless, the ethnography can be considered as a complex weaving of time, space, voices and multiple texts, it goes beyond mere terminology (Thompson \& Hunston). The ethnography is built along communicative situations as the following outline illustrates (Van Dijk, 231):

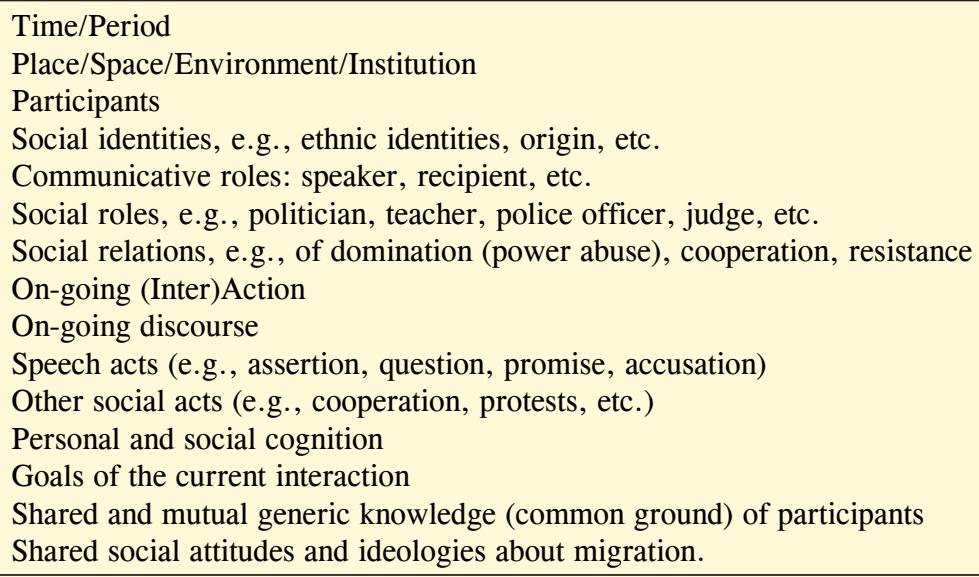

Thus, in proposing a translation into Portuguese of The death and life of Aida Hernandez, the above outline can be considered in relation to Munday's detailed discussion on evaluation in translation in which the focus is on microtextual elements, related to values and emotions (Munday). Aida's trajectory to the United States and her lifestory in general involve trauma as well as value judgements:

emphasis on 'model immigrants' and the 'deserving poor' can help win important improvements for select groups, but it falls short for the vast majority of people - people with tougher, more complicated stories (Bobrow-Strain, 344).

There are values embedded in dislocation, circularity, mobility and trauma. Ethnography is built around value-judgements. Thus, 
appraisal theory: "provides a possible model for the recognition and analysis of the lexical signals and realizations of value insertion" (Munday, 40-41). The question of value insertion can be approached in various senses. The writer, the translator, the protagonists in the ethnography as well as the readers are ideologically engaged voices. The writer's explanation as to how he constructs the ethnography offers sensitive information for possible translation of The death of Aida Hernández. The excerpts below reveal the author's concern with the complexities and trauma embedded in his ethnography that is not just a simple transnational habitus:

AIDA LEFT TUCSON with a thirty-day immigration parole to receive followup care in the United States. Humanitarian parole was a strange contrivance of logjammed immigration law. It allowed Aida to be present in the United States without legally admitting her to the country. The border wall wrapped around her body as she left the hospital. Physically, she existed inside the United States; legally, she floated outside. Her mental state matched the unusual legal status. Her physical wounds had begun to heal, but the attach had cut her in places she couldn't yet fathom (Bobrow-Strain, 175).

Aida's trials and triumphs should make us skeptical about the way that many immigrant, stories, pro and con, stick to black-and-white binaries: the rulebreaker and the hard worker, the criminal alien and the model immigrant. In our political moment, the "good" immigrant, worth of sympathy and rights, does not exist without its foil: the alien who has made mistakes and therefore deserves the punishment she gets. But Aida's life - and the lives of most immigrants - are messier than those binaries (Bobrow-Strain, 352).

...The Death and Life of Aida Hernandez is not really about Aida Hernandez. It is a story told in collaboration with Aida about the brutal consequences of policies she was, in Audre Lorde's poetic language, "never meant to survive.". Her hard-won expert knowledge of systems and policies that few Americans understand, and her willingness to share that knowledge, made this book possible (Bobrow-Strain, 350).

Finally, I said that I would do my best to portray her as a real person, not a saint or a demon. If we proceeded, it was important to tell a complex human story independent of the larger political and economic issues swirling around it. Aida's story would matter on its own, not just as a representative type of "immigrant experience" (Bobrow-Strain, 346). 
The first shift in our relationship came when I shared my own history of debilitating anxiety. It poured out unexpectedly after what would prove to be the first of many of Aida's crises I witnessed (Bobrow-Strain, 345).

The ethnographer's role obviously choices. His transnational habitus is not just about cultural issues or terminology; it is about lifeworlds and institutional parameters. There is a sociology of actors (Walters, op. cit.). According to Rudvin (159), power is negotiated, manipulated, expressed, rejected and challenged interpersonally in contexts and discourse, defined according to asymmetries in institutional power. Today, the institutional scenario is built around interaction and bureaucratic "optimization" - there are "parameters" and "conventions" between participants (Arminen, 442). Rudvin also discusses the translator's role and the choices underlying text translation: Translation/Interpreting Theory is sociologically aware, with its "shift away from a positivist, essentialist as well as linguistically based approach to a more holistic and relativist methodology taking into account ... political inclinations and motivations, cultural difference, power relations and hierarchies ... contributing to the formation of "meaning"' (Rudvin, 2).

Thus, in proposing a translation of an ethnography on the complexities of U.S.- Mexico border life, the translator's role has to be carefully considered. According to Bujra: "Choosing a translator requires attention to the social dynamics between researcher, interpreter and respondents" (172). According to Bogusia and Young: There is no neutral position from which to translate and the power relationships within research need to be acknowledged (164). Ethnography does not begin on neutral ground - knowledge is constructed and positioned:

People like Aida and those around her - people who have led messy, human lives, struggling against difficult odds - have forged legitimate places for themselves in their communities and country. They should be given a chance to establish this belonging under the law, and not just by 
defining themselves as supplicant victims. They are active makers of their communities and nation (353).

The ethnographer is ideologically visible within the text (Howell et al.,). The Death of Aida Hernandez is an ideoscape, the translator therefore should work from within this knowledge construct:

\begin{abstract}
All these approaches to knowledge and how it is produced acknowledge that your location within the social world influences the way in which you see it. If you subscribe to this view of social reality, then translators must also form part of the process of knowledge production. There is no neutral position from which to translate and the power relationships within research need to be acknowledged (164).
\end{abstract}

Ethnography is a composite genre: history, narrative, public discourse, trauma written in the dominant language of English, but spliced with the split language space of U.S.-Mexico border life. Therefore, translation of an ethnography requires a translator who must work from a critical language perspective, micro-textual choices must be made from sensitive engagement so that the complex ethos of immigration ideoscapes is captured (Appadurai, 33; Radhay). The politics of translation is thus not a binary border game - a simple crossing from one language to another but must be based upon engaged agency and social relevance (Inghilleri) in a sensitive ethnography like The death and life of Aida Hernandez. 


\section{References}

Amicelle, A. et al., "Criminology in the face of flows: reflections on contemporary policing and security". GLOBAL CRIME. V. 18, No. 3, Taylor \& Francis, (2017): 165-175.

Anderson, B. Nação. Consciência nacional. Trad. L.L de Oliveira. São Paulo: Ática, 1989.

Andrews, Molly. "Opening to the original contributions: counter-narratives and the power to oppose", Considering counter-narratives: narrating, resisting, making sense. Vol. 4, Bamberg, Michael; Molly, Andrews (Orgs.), Amsterdam and Philadelphia: John Benjamins Publishing Company, 2004.

Angermuller, J. "Truth after post-truth: for a Strong Programme in Discourse Studies”. Palgrave Communications. (2018): 1- 8.

Appadurai, A. Modernity at large: cultural dimensions of globalization. Minnesota: University of Minnesota Press, 1996.

Arcarazo, D. \& Freier, L. "Discursos y políticas de inmigración en sudamérica: ¿hacía un nuevo paradigma o la confirmación de una retórica sin contenido?”. REMHU. Ano XXIII, n. 44, jan/jun 2015: 171-189.

Argaman, E. "Arguing within an institutional hierarchy: how argumentative talk and interlocutors' embodied practices preserve a superior-subordinate relationship". Discourse \& Society, Vol. 11 (5), (2009): 515-541.

Arminen, I. "On the context sensitivity of institutional interaction". Discourse \& Society, 11 (3), (2000): 435-458.

Baker, M. Translation and conflict: a narrative account. London: Routledge, 2006.

Baker, M. "Translation and Activism: Emerging Patterns of Narrative Community". The Massachusetts Review; Fall 47, 3. 2006. 
Balibar, E. "At the borders of citizenship: A democracy in translation?". European Journal of Social Theory, 13 (3), (2010): 315-322.

Bhaba, H. Lynn Mario de Souza entrevista Homi Bhaba. Youtube. web. 2021. Disponível em: https://youtu.be/ExBfigM2_ec.

Bhaba, H. Translation and displacement. CUNY Graduate Center, 2016. Disponível em: https://youtu.be/TVQcdbSV6OI.

Blommaert, J. "Language, Asylum, and the National Order". Current Anthropology, v. 50, $\mathrm{n}^{\mathrm{O}} .4$, (2009): 415-441.

Bloor, D. Knowledge and social imagery. 2nd ed. Chicago: The University of Chicago Press, 1991.

Bobrow-Strain, Aaron. The death and life of Aida Hernandez: a border story. New York: Farrar, Strauss and Giroux, 2019.

Bogusia, T. \& Young, A. "Qualitative research and translation dilemmas". Qualitative Research. Vol. 4(2), (2004): 161-178.

Bosworth, M. Inside detention centres. Oxford: Oxford University Press, 2014.

Bujra, J. "Lost in translation? The use of interpreters in fieldwork". Doing development research, Desai, V. \& Potter, R.B. (Eds.), New York: Sage Publications, 2006.

Capstick, T. "Resisting Discriminatory Immigration Procedures and Practices in the UK and Pakistan: A Discourse-Ethnographic Approach to Exploring Migration Literacies". Sociolinguistic Perspectives on Migration Control Language Policy, Identity and Belonging, Rheindorf, M \& Wodak, R. (Eds.), Bristol: Multilingual Matters, 2020.

Carminero-Santangelo, M. Documenting the undocumented. Florida: University Press of Florida, 2017. 
Ceyhan, A. \& Tsoukala, A. "The securitization of migration in Western societies: ambivalent discourses and policies". Alternatives: global, local, political. 27(1), Boulder: Lynn Rienner Publishers, 2002.

Chilton, P. "Political terminology". The handbook of communication in the public sphere, R. Wodak, \& V. Koller (Ed.), Berlim: Mouton de Gruyter, 2008, 225$242 \mathrm{pp}$.

Chilton, P. Analysing political discourse. Theory and practice. London: Routledge, 2004.

Christian J.; Churchill, Jr. "Ethnography as Translation". Qualitative Sociology, Vol. 28, $\mathrm{n}^{\circ}$. 1, Spring (2005).

De Fina, A. Identity in narrative. A study of immigrant discourse. Amsterdam \& Philadelphia: John Benjamins, 2003.

Dijk, van, T. "Discourse and Migration". Qualitative Research in European Migration Studies, Ricard Zapata-Barrero \& Evren Yalaz (Eds.), Helsinki: Imiscoe Research Studies, 2018, 227-246pp.

Dijk, van, T. Discourse and knowledge: A sociocognitive approach. Cambridge, United Kingdom: Cambridge University Press, 2014.

Dijk, van, T. "Discourse and knowledge". The Routledge Handbook of Discourse Analysis, J.P. Gee \& M. Handford (Eds.), London: Routledge, 2012, 587-603 pp.

Dijk, van, T. "Discurso de las élites y el racismo institucional". Medios de comunicación e inmigración, C. Padilla (Org.), Santo Ángel: Convivir sin racismo, 2006.

Domenech, E. "Inmigración, anarquismo y deportación: la criminalización de los extranjeros 'indeseables' em tiempos de las 'grandes negociaciones'. REMHU - Revista Interdisciplinar Mobilidades Humanas. Brasília, Ano XXIII n. 45, (2015): 165-186.

Duchêne, A.; Moyer, M. \& Roberts, C. Language, migration and social inequalities. Bristol: Multilingual Matters, 2013. 
Ellis, D. Legitimising Immigration Control Policy in the UK A Critical Discourse Analysis of the Conservative Party's Immigration Act 2016. Dissertation, School of Applied Social Science, University of Brighton, (2017)

Gentzler, E. Translation and identity in the Americas: new directions in translation theory. London: Routledge, 2012.

Gustafsson, Kristina; Eva, Norström; Ingrid, Fioretos. "The interpreter: a cultural broker?". Interpreting in a changing landscape: Selected papers from Critical Link 6, Christina Schäffner, Krzysztof Kredens, Yvonne Fowler (Eds.), Amsterdam: John Benjamins Publishing Company. Benjamins Translation Library http://dx.doi.org $\backslash 0.1075 \backslash$ btl.109, (2013): 187-202.

Gustavson, L.; Cytrnbaum, J. "Illuminating spaces: relational spaces, complicity, and multisited ethnography". Field Methods, 15 (3), (2003): 252-270.

Howell et al., (Eds.). "Porous Borders, Invisible Boundaries? Ethnographic Perspectives on the Vicissitudes of Contemporary Migration". A Publication of the Committee on Refugees and Immigrants Society for Urban, National, and Transnational/Global Anthropology American Anthropological Association, (2018).

Ibrahim, Maggie. "The Securitization of Migration: A Racial Discourse". International Migration. 43 (5), (2005): 163-87.

Inghilleri, Moira. "The Sociology of Bourdieu and the Construction of the 'Object' in Translation and Interpreting Studies”. The Translator. 11:2, (2005): 125-145.

Inowlocki, L.; Lutz, H. "The 'biographical work' of a turkish migrant woman in germany”. The European Journal of Women's Studies. 7: (2000): 301-319.

Marinucci, R. "Mobilizações de migrantes e refugiados: as lutas pela visibilidade e pelo reconhecimento". REMHU, v.24, $\mathrm{n}^{\mathrm{0}} .48$, (2016): 7-10.

Marinucci, R. "Criminalização das migrações e dos migrantes". REMHU, v.23, $\mathrm{n}^{0} .45,(2015): 7-10$. 
Munday, J. Evaluation in translation. Critical points of translator decisionmaking. London: Routledge, 2012.

Oberhuber, F. "Dissemination and implementation of political concepts". In: Oliveira, C. M. S. Migração, etnicidade e identidade no Brasil. Revista eletrônica de ciências sociais. Centro de Ciências humanas, Letras e Artes, Universidade Federal da Paraíba, Vol. 3 (2001):1-5.

Polezzi, L. "Translation and migration". Translation Studies. Vol. 5, $\mathrm{n}^{\mathrm{o}} 3$, (2012): 345-368.

Radhay, R. Pertencimento: ideoscapes institucionais e retratos de imigrantes na imigração sul-sul no Brasil: a documentação institucional e comunitária. Pittsburgh: Working Paper, LASA, 2019.

Reisigl, M., \& Wodak, R. "The discourse-historical approach (DHA)". Methods of Critical discourse analysis, R. Wodak \& M. Meyer (Eds.), London, England: Sage Publications Ltd, 2016, pp. 23-61.

Rudvin, M. "Power behind discourse and power in discourse in community interpreting: the effect of institutional power asymmetry on interpreter strategies". Revista Canaria de Estudios Ingleses, 51, (2005): 159-179

Rudvin, M. "Community interpreting in the area of mental health: psychosocial implications of interpreting strategies". Conference paper for the Issues in Interpreting Research Conference, Manchester, 2000.

Santa Ana, O. Brown tide rising. Metaphors of latinos in contemporary American public discourse. Texas: University of Texas Press, 2002.

Santa Ana. "'Like an animal I was treated': anti-immigrant metaphor in US public discourse”. Discourse \& Society 10 (2), (1999): 191-224.

Silverman, S.J. The normative ethics of immigration detention in liberal states. Doctoral thesis, St. Anthony's College, University of Oxford, 2013. 
Schölten, P. "Research Policy Relations and Migration Studies". Qualitative Research in European Migration Studies, Ricard Zapata-Barrero \& Evren Yalaz, Helsinki: Imiscoe Research Studies, 2018, 287-302 pp.

Strauss, C. "How are language constructions constitutive? Strategic uses of conventional discourses about immigration". Journal of International Relations and Development, 16(2), (2013): 262-293.

Stumpf, J. The crimmigration crisis: immigrants, crime, and sovereign power. Stanford: Stanford University Press, 2013.

Sturge, K. "Translation strategies in ethnography". The Translator. Volume 3, (1), (1997): 21-38.

Thompson, G; Hunston, S. Evaluation in Text: Authorial Stance and the Construction of Discourse. Oxford: Oxford University Press, 2000.

Valero-Garcés, C. "Modes of Translating Culture: Ethnography and Translation". Meta, 40 (4), (1995): 556-563.

Van Leeuwen, T. "Legitimation in discourse and communication". Discourse \& Communication. Vol 1(1) Sage Publications, (2007): 91-112.

Walters, W. "Foucault and frontiers: notes on the birth of the humanitarian border". London: U. Brockling/Routledge, 2010.

Williams, H. "Changing the National Narrative: Evolution in Citizenship and Integration in Germany", 2000-10. Journal of Contemporary History. 49(1), (2014): 54-74.

Wodak, R. \& Koller. V. The handbook of communication in the public sphere. Berlim: Mouton de Gruyter, 2008.

Wodak, R.\& Meyer, M. Methods of Critical discourse analysis. New York: Sage Publications Ltd., 2016. 
Zapata-Barrero, .R.; Van Dijk, T. A. "Introducción: inmigración y discurso". Discursos sobre la inmigración en España. Los medios de comunicación, los parlamentos y las administraciones, Zapata-Barrero, R. y van Dijk, T. A. (Eds.), Barcelona: Fundación CIDOB, 2007, pp. 9-14.

Recebido em: 03/12/2020

Aceito em: 25/03/2021

Publicado em maio de 2021

Rachael Anneliese Radhay. E-mail: radhayrachael@gmail.com. ORCID: https:// orcid.org/0000-0001-8143-0974. 